\title{
sciendo
}

\section{Investigating how online shopping platform users contribute to improving the businesses' performance: empirical evidence from Romania}

\author{
Andreea BARBU \\ University POLITEHNICA of Bucharest, Bucharest, Romania \\ andreea.barbu2901@upb.ro \\ Gheorghe MILITARU \\ University POLITEHNICA of Bucharest, Bucharest, Romania \\ gheorghe.militaru@upb.ro \\ Cristina Petronela SIMION \\ University POLITEHNICA of Bucharest, Bucharest, Romania \\ petronela.simion@upb.ro \\ Georgiana MOICEANU \\ University POLITEHNICA of Bucharest, Bucharest, Romania \\ georgiana.moiceanu@upb.ro
}

PICBE | 373

\begin{abstract}
The purpose of this paper is to identify how online shopping platform users in Romania influence businesses' performance. The emergence of e-commerce has led to a revolution in global commerce by diversifying and improving sales and purchasing actions for existing products and services on the market. In Romania, buyers' behaviour shows a more restraining of online commerce behaviour. Most sales are still registered according to the classic system of physically going to stores, although the number of online users has grown significantly over the last decade. The reluctance of buyers to buy from the online environment leads to the low performance of companies in the e-commerce market. The hypothesized model is empirically tested using data collected from a survey on Google Analytics platforms of some online companies in Romania. The authors used SPSS Software to examine the reliability and validity of the measurement model. There have been analysed various links between some variables that were obtained from Google Analytics, data that were collected by age groups, gender or geographical area. Through an empirical analysis is being analysed the role of tracking data on the websites in order to improve company performance. By analysing those variables, the authors analysed if the number of sessions acquired, the bounce rate of the acquired visitors or other variables can improve the company performance. This study offers a new perspective on company performance in online firms. The analysis of variables describing user behaviour in the online environment in interaction with $e$ commerce platforms has led to conclusions about the performance of online companies. The theoretical contributions and managerial implications of the study are discussed.
\end{abstract}

Keywords: company performance, industrial services performance, online business performance, online services, business digitization, e-commerce. 


\section{Introduction}

In the last years, researches from all over the world have started to study different ways to measure the performance of the companies, being interested in improving their businesses' evolution.

At first, managers used financial performance measures to monitor the progress of a company, but as the competition intensified, they realized that there are other non-financial performance measures that can offer them valuable information about both the company and its position in relation to competitors (Hemmer, 1996).

One of the most known models of measuring business performance is Balanced Scorecard, which was developed by Kaplan and Norton (1992) as a result of the managers' need of planning, taking strategic decisions or controlling the company (Banker \& Johnston, 1995). This model has been widely accepted by most managers and researchers, but the problem came with the emergence of online businesses and the e-commerce era when companies started using websites to their activity.

Taking into account that a website is most often the link or even the only link between companies and customers (Ghandour et al., 2011), the managers have started to be preoccupied about recording the performance of the official site of the companies.

Determining the performance of the online companies is not so easy to do, because managers should be careful at both financial measures and online measures, trying to figure out what kind of decisions they need to take to improve the performance of the company.

The purpose of this paper is to study different data that are characteristics for a website in order to analyse the behaviour of the customers that are buying services or products online, and to study if there are any connections between this kind of data and financial data when we are trying to determine the performance of a company. This paper is structured as follows. In the first section, the authors presented the necessary background literature for explaining the state-of-the-art in the online performance measuring domain of the present research. Then, they presented the methodology for the research. In the next section, the authors discussed the results of their study, while the last section was reserved for conclusions.

\section{Literature review}

\section{Online business performance}

In the last period of time, researchers have begun to write more and more papers about companies' performance and how this can be improved, especially given that technology is evolving very quickly and we can use it both to ease our work in organizations and to facilitate processes for evaluating the performance of these organizations.

As defined by many authors, performance can be viewed as the result of the interaction of productivity, competitiveness, and profitability (Jacot, 1997; Pottier, 2000; Sink \& Tuttle, 1989; Niculescu \& Lavalette, 1999).

Over time, there were various methods, models and techniques used to measure performance, some more well-known, such as the Balanced Scorecard method, and less well known.

Balanced Scorecard was developed by Kaplan and Norton (1992) as a way to combine both financial and non-financial metrics of performance. They highlighted the fact that financial metrics are used to analyse past events and proposed three other dimensions to 
come in completing the first one to provide an overview of the company's future evolution. Thus, according to the Balanced Scorecard method, we should analyse the company's performance from the four perspectives: financial, internal processes, customers and the firm's innovation and learning processes.

The financial perspective can be used for presenting the main indicators that are important for the shareholders (like cash flow or other indicators related to profitability),the internal perspective analyse the way we can improve the efficiency of the internal processes and operations, the customer perspective analyse what kind of elements are important for customers when they are interacting with the firm, while the innovation and learning perspective is used for determining what types of strategies companies use to stay competitive on the market and to improve their activity through innovation and learning.

Thus, thanks to Kaplan and Norton (1992), the road to performance measurement was opened, leaving the researchers free to find the right combination of financial and nonfinancial factors that can measure the performance of a company.

\section{Companies' online performance}

The problem of measuring company performance becomes even more complicated when it comes to online business activity.

Jamshed Mistry (2001) highlighted in his work the fact that researchers have tried to apply the Balanced Scorecard method for the companies that operate online. In his work, he used the same four perspectives for measuring the performance of an online store, using as the key performance indicators those that are presented in Table 1.

Table 1. Key Performance Indicators for the Balanced Scorecard dimensions

\begin{tabular}{|c|c|c|c|c|}
\hline & \multicolumn{4}{|c|}{ Perspective } \\
\hline & Financial & Internal Process & Customer & Innovation \\
\hline $\begin{array}{l}\text { Key } \\
\text { performance } \\
\text { indicators }\end{array}$ & $\begin{array}{l}\text { Funding; } \\
\text { Revenue; } \\
\text { Net income }\end{array}$ & $\begin{array}{l}\text { Customer Conversion } \\
\text { Factor; } \\
\text { Revenue/Technical / } \\
\text { Dev. expenditure; } \\
\text { Revenue/ Marketing } \\
\text { Expenditure }\end{array}$ & $\begin{array}{l}\text { Customer } \\
\text { Conversion } \\
\text { Factor; } \\
\text { Customer } \\
\text { Profitability; } \\
\text { Profitability per } \\
\text { customer; } \\
\text { Customer } \\
\text { contribution; } \\
\text { Revenue per } \\
\text { customer }\end{array}$ & $\begin{array}{l}\text { Employee Value; } \\
\text { Revenue/Employee; } \\
\text { Employee Profitability; } \\
\text { Profitability/Employee; } \\
\text { Customers/ } \\
\text { Technical-Dev. } \\
\text { expenditure }\end{array}$ \\
\hline
\end{tabular}

Source: Adapted from Mistry, J. (2001)

Over time, many authors have approached the theme of website performance measurement (Auger, 2005; Adam \& Deans, 2001; Brynjolfsson \& Hitt, 2000; Porterfield et al., 2010). Unfortunately, there has been no consensus on a set of criteria that can be used to measure the performance of online selling products or services.

Most of the time, the criteria used are simple, and are chosen according to the perspective of the user, the designer or the owner (Ghandour et al., 2011) but also can be complicated by using individual or organisational levels (Molla \& Licker, 2001) or different combinations of items from different dimensions (Segars \& Grover, 1998). 
There are many approaches to measuring online site performance in the literature, most of them measuring the satisfaction of the users and studying the correlations between this satisfaction and their probability to buy online from those companies (Udo \& Marquis, 2001).

Another approach concerns web analytics that allows both businesses and merchants to track the behaviour of website users and analyse how this behaviour can affect their purchasing decision (Garcia et al, 2016).

There are a lot of tools used to analyse websites and to measure its various indicators, one of the best-known tools being Google Analytics.

Google Analytics is a web analytics service offered by Google which helps you collect traffic data from your online properties, process that data, and report on it so you can make informed business decisions.

With Google Analytics, you can track various useful details, such as traffic volume, whereabouts (sites, social media, Google searches, ad campaigns, etc.), site/app. behavior, online conversions, etc.

You can access the information in Google Analytics only if you own or work for that site or that application, with access only to the information available for that company. If you want to monitor your competitors, you can use other (generally paid) tools such as SimilarWeb, SEMrush and so on (Bojincă-Moisei, 2017).

Google Analytics has six main categories of reports: Real-time, Audience, Acquisition, Behaviour, Conversions, and Discover. Here you can observe different metrics (dimensions that can be given a quantifiable value, such as Pages/ Session, Pageviews, Average Session Duration) and analyse them in order to take the right decisions about the company. In table 2 it can be observed some of the most important terms used in Google Analytics (Lewis, 2013; Bojincă-Moisei, 2017).

Analysing the existing papers from different scientific databases, we found that there are still issues and gaps in the relation between the performance indicated by the use of online sites and the overall performance of the company. Maybe this problem also comes from the fact that performance is an umbrella term, a complex concept that involves complex analysis between several dimensions.

For this paper, the authors used a part of the way Ghandour et al. (2011) measured the performance of a website, choosing 2 dimensions for our study: financial factor and usage factor. Financial factor is very important for a company that sells goods or services online, bringing specific information about the results that are recorded as a result of online transactions. The website usage factor was demonstrated to be an important construct which affects the performance impact of information technology (Ghandour et al., 2011). In this dimension, we can analyse information such as visitor traffic and activities on websites. 
Table 2. Terms and definitions used in Google Analytics

\begin{tabular}{|l|l|}
\hline Terms & Definitions \\
\hline Acquisition & The way you get visitors (users) \\
\hline Audience & The total of people interacting with the site \\
\hline $\begin{array}{l}\text { duration } \\
\text { Behaviour }\end{array}$ & Average time spent by visitors on the site or in the app \\
\hline Bounce rate & $\begin{array}{l}\text { The percentage of visits that ended after the first viewed page, then those visitors } \\
\text { leaving the site }\end{array}$ \\
\hline Conversion & $\begin{array}{l}\text { The percentage of visits to your site or app that has led to an action you want (for } \\
\text { example subscribing to the newsletter, signing up for an event, buying a product) }\end{array}$ \\
\hline Pages / session & Average number of pages visited in a single browsing session \\
\hline Page views & Total number of pages visited in a time unit \\
\hline Sessions & $\begin{array}{l}\text { Visits to your site or app. A session is determined by the amount of time the user } \\
\text { interacts directly with the site. }\end{array}$ \\
\hline Users & $\begin{array}{l}\text { Visitors who have had at least one session within the set timeframe. Include both } \\
\text { new and returning users }\end{array}$ \\
\hline $\begin{array}{l}\text { E-commerce } \\
\text { Conversion Rate }\end{array}$ & $\begin{array}{l}\text { The percentage of visits that resulted in an e-commerce transaction } \\
\text { [(Transactions / Visits) } * 100 \text { ] }\end{array}$ \\
\hline Revenue & Income that your website generates \\
\hline Transactions & The number of transactions that are made through your site \\
\hline Site Speed & How quickly users are able to see and interact with the online content. \\
\hline
\end{tabular}

Source: Adapted from Lewis, 2013, \& Bojincă-Moisei, 2017

Thus, what the authors of this paper proposed is to determine whether the financial performance of the company is influenced by the financial performance measured on the company's website or by the way the users interact with the website. In order to do that, we chose to analyse this problem in the context of the industrial services.

In order to do that, the authors wanted to answer the following questions:

Q1: Is net turnover influenced by the numbers of online visitors of the official site of an industrial company that sells services or goods online?

Q2: Is there any correlation between net turnover and E-commerce conversion rate?

Q3: What are the elements that influence the revenues obtained from online transactions?

Q4: Is there a relationship between net turnover and stock value?

\section{Methodology}

The aim of this paper is to study if there is a link between industrial service performance and the behaviour of online shopping users in this sector. For this paper, the authors collaborated with a Romanian company that was founded in 2005. This company deals with hosting services, creating online stores, graphics creation for print/web, product photography, online advertising, and marketing consulting / IT \& C.

From their portfolio consisted in 824 online stores, we chose to analyse only the industrial services companies that were having an online store. In this phase, we identified 36 companies.

We wanted to test the results recorded by those companies in 2017 because we wanted to correlate them with the financial information that we could obtain by interrogating the official site of the Romanian Ministry of Finance. Thus, for the next phase, 
we checked how many companies from those identified had online activity at least in 2017. From those 36 companies, we had remained with only 10 companies.

The last step was to check if those 10 companies were having a conversion rate. We chose this indicator because we need to analyse the relationship between the online and the financial performance of an online store. For this phase, the authors used the Google Analytics tool and found that only 8 of the ten companies were representative for our research.

For further examination, we needed three tools: the official site of the Romanian Ministry of Finance, Google Analytics, and also SPSS 20.0 software.

For better interpretation and to respect the confidentiality of data, the eight companies in the field of industrial services will receive one code from $\mathrm{A}$ to $\mathrm{H}$.

From the official site of the Romanian Ministry of Finance, we searched the 8 companies based on their unique identification codes in order to get identification data, tax information, and balance sheets.

From this phase, we obtained information for the year 2017 such as founding year of the company (Y), the number of employees (E), Net turnover value (NT), and the value of the stocks (S).

From Google Analytics, the authors analysed the 5 main dimensions that were available on the internet: Real-Time construct, Audience construct, Acquisition construct, Behaviour construct and Conversions construct. Taking into account that our analysis only targeted data in 2017, we removed from our analysis the Real-Time dimension.

In Table 3 it can be observed the most important data that were analysed for each construct.

Table 3. Analysed items and dimensions

\begin{tabular}{|l|l|l|l|}
\hline Audience & Acquisition & Behaviour & Conversions \\
\hline Age & Top channels & Number of visits/ page & E-commerce conversion rate \\
\hline Gender & Conversions & Number of new visitors & Revenue \\
\hline Device & Location & Number of returning visitors & \\
\hline & Transactions & Number of total visitors & \\
\hline & & Bounce rate & \\
\hline & & Site Speed & Source: Authors' own research \\
\hline
\end{tabular}

\section{Results and discussions}

In this section, the author presents the main findings of his/her research. It is important to use critical thinking in order to analyse realistically the results obtained, and how the research hypotheses have been validated or not. Also, it is important to compare the results of the present research with results obtained in similar research, by using the literature in the domain. If the paper presents a theoretical model or theory, the discussion should be about the way the new conceptual contribution can be applied and how it compares with some similar models or theories.

In Table 4 there are presented the main results that were obtained via the official site of the Romanian Ministry of Finance. It can be observed that $37.5 \%$ of them were founded between 1990 and 2000; also 37.5\% were founded between 2000 and 2010 while the rest of $25 \%$ were founded after 2015. Also, it is important to highlight that their number of employees is less than 10 , information that makes us think about whether the number of 
employees can be influenced by the fact that the company's activity can take place online and that there is no need for physical presence of some people to provide various industrial.

Table 4. General data on research companies

\begin{tabular}{|c|c|c|c|c|}
\hline Company & $\begin{array}{l}\text { Founding } \\
\text { Year }\end{array}$ & Net turnover (RON) & $\begin{array}{l}\text { Number of } \\
\text { Employees }\end{array}$ & $\begin{array}{l}\text { Value of Stocks } \\
\text { (RON) }\end{array}$ \\
\hline A & 2014 & 1.187 .543 & 3 & 268.796 \\
\hline B & 1994 & 11.898 .255 & 7 & 773.572 \\
\hline $\mathrm{C}$ & 1994 & 1.142 .889 & 4 & 645.370 \\
\hline $\mathrm{D}$ & 2016 & 111.850 & - & 8.847 \\
\hline E & 2009 & 747.943 & 2 & 58.162 \\
\hline $\mathrm{F}$ & 2009 & 337.348 & 3 & 87.512 \\
\hline G & 2002 & 2.212 .483 & 6 & 291.845 \\
\hline $\mathrm{H}$ & 1994 & 11.898 .255 & 7 & 773.572 \\
\hline
\end{tabular}

Source: Authors' own research

For Table 5, the authors used information from Google Analytics tools. It can be observed the number of users, the average bounce rate, the value of revenues and the number of transactions that are represented for each of the analysed companies based on the device that was used by the online users. For all of the eight companies, the mobile device was preferred by users, but the number of transactions and the value of revenues didn't depend on the user device.

After collecting other data from Google Analytics, the authors used SPSS software in order to test if there is any correlation between the financial factor and online usage factor.

First, the authors used Cronbach's alpha coefficients in order to determine the internal consistency of items in each scale. As it can be seen in Table 6, the Cronbach's alpha value is 0,916 for financial performance and 0,913 for online performance, values that are greater than 0,7, as Hair at al. (2007) has recommended this minimum level for minimum high reliability. Also, the authors tested the factor loadings for each item. All of the analysed items have a value between 0,684 and 0,980 , meaning that they are statistically significant according to Fornell and Larker (1981) who said that the minimum accepted value for factor loadings is 0.5 . 
Table 5. Information about devices used by online users during 2017

\begin{tabular}{|c|c|c|c|c|c|}
\hline Company & Device & Number of Users & Average of Bounce Rate & Revenue (RON) & Transactions \\
\hline \multirow{4}{*}{ A } & Desktop & 3.357 & $44,19 \%$ & 5.862 & 27 \\
\hline & Mobile & 4.436 & $49,56 \%$ & 3.365 & 27 \\
\hline & Tablet & 382 & $42,65 \%$ & 263 & 3 \\
\hline & Grand Total & 8.175 & $45,46 \%$ & 9.490 & 57 \\
\hline \multirow{4}{*}{ B } & Desktop & 21.643 & $63,09 \%$ & 64.243 & 144 \\
\hline & Mobile & 47.353 & $52,53 \%$ & 417.885 & 824 \\
\hline & Tablet & 1.882 & $58,04 \%$ & 6.792 & 19 \\
\hline & Grand Total & 70.878 & $57,89 \%$ & 488.920 & 987 \\
\hline \multirow{4}{*}{ C } & Desktop & 9.416 & $52,19 \%$ & 120.943 & 176 \\
\hline & Mobile & 13.119 & $69,00 \%$ & 26.211 & 118 \\
\hline & Tablet & 1.152 & $66,96 \%$ & 2.943 & 11 \\
\hline & Grand Total & 23.687 & $62,72 \%$ & 150.097 & 305 \\
\hline \multirow{4}{*}{$\mathrm{D}$} & Desktop & 800 & $71,00 \%$ & 88 & 1 \\
\hline & Mobile & 1.581 & $60,72 \%$ & 2.878 & 9 \\
\hline & Tablet & 66 & $64,44 \%$ & - & - \\
\hline & Grand Total & 2.447 & $65,39 \%$ & 2.966 & 10 \\
\hline \multirow{4}{*}{$\mathrm{E}$} & Desktop & 2.718 & $46,40 \%$ & 8.915 & 52 \\
\hline & Mobile & 3.101 & $51,49 \%$ & 3.730 & 45 \\
\hline & Tablet & 206 & $48,05 \%$ & 345 & 5 \\
\hline & Grand Total & 6.025 & $48,65 \%$ & 12.990 & 102 \\
\hline \multirow{4}{*}{$\mathrm{F}$} & Desktop & 40.510 & $49,61 \%$ & 70.270 & 1.151 \\
\hline & Mobile & 51.439 & $42,75 \%$ & 157.763 & 2.236 \\
\hline & Tablet & 4.090 & $43,65 \%$ & 7.624 & 120 \\
\hline & Grand Total & 96.039 & $45,33 \%$ & 235.657 & 3.507 \\
\hline \multirow{4}{*}{ G } & Desktop & 2.745 & $46,87 \%$ & 9.004 & 52 \\
\hline & Mobile & 3.132 & $52,01 \%$ & 3.767 & 45 \\
\hline & Tablet & 208 & $48,53 \%$ & 348 & 5 \\
\hline & Grand Total & 6.085 & $49,13 \%$ & 13.119 & 102 \\
\hline \multirow{4}{*}{$\mathrm{H}$} & Desktop & 2.098 & $67,62 \%$ & 4.098 & 14 \\
\hline & Mobile & 10.365 & $59,30 \%$ & 16.128 & 57 \\
\hline & Tablet & 218 & $64,07 \%$ & - & - \\
\hline & Grand Total & 12.681 & $63,66 \%$ & 20.226 & 71 \\
\hline
\end{tabular}

Source: Authors' own research 
Table 6. Factor loadings and Cronbach's alpha

\begin{tabular}{|c|c|c|}
\hline Variable & Factor Loadings & Cronbach's alpha \\
\hline Financial factor & & $\mathbf{. 9 1 6}$ \\
\hline Net turnover & .980 & .889 \\
\hline Value of stocks & .932 & .889 \\
\hline Usage factor & & .913 \\
\hline Avg. Page Load Time & .684 & .569 \\
\hline New visitors & .866 & .842 \\
\hline Returning visitors & .864 & .825 \\
\hline Total visitors & .866 & .842 \\
\hline Transactions & .981 & .924 \\
\hline Revenue from online transactions & .902 & .906 \\
\hline E-commerce Conversion Rate & .851 & .736 \\
\hline
\end{tabular}

Source: Authors' own research

We have tested a multiple linear regression to determine the elements that could influence the value of the Net turnover variable. In this sense, we chose Net turnover as the dependent variable, and the independent variables: Transactions, Bounce Rate, Returning visitors, Total visitors, Returning visitors (Table 7).

Table 7. Coefficients ${ }^{a}$

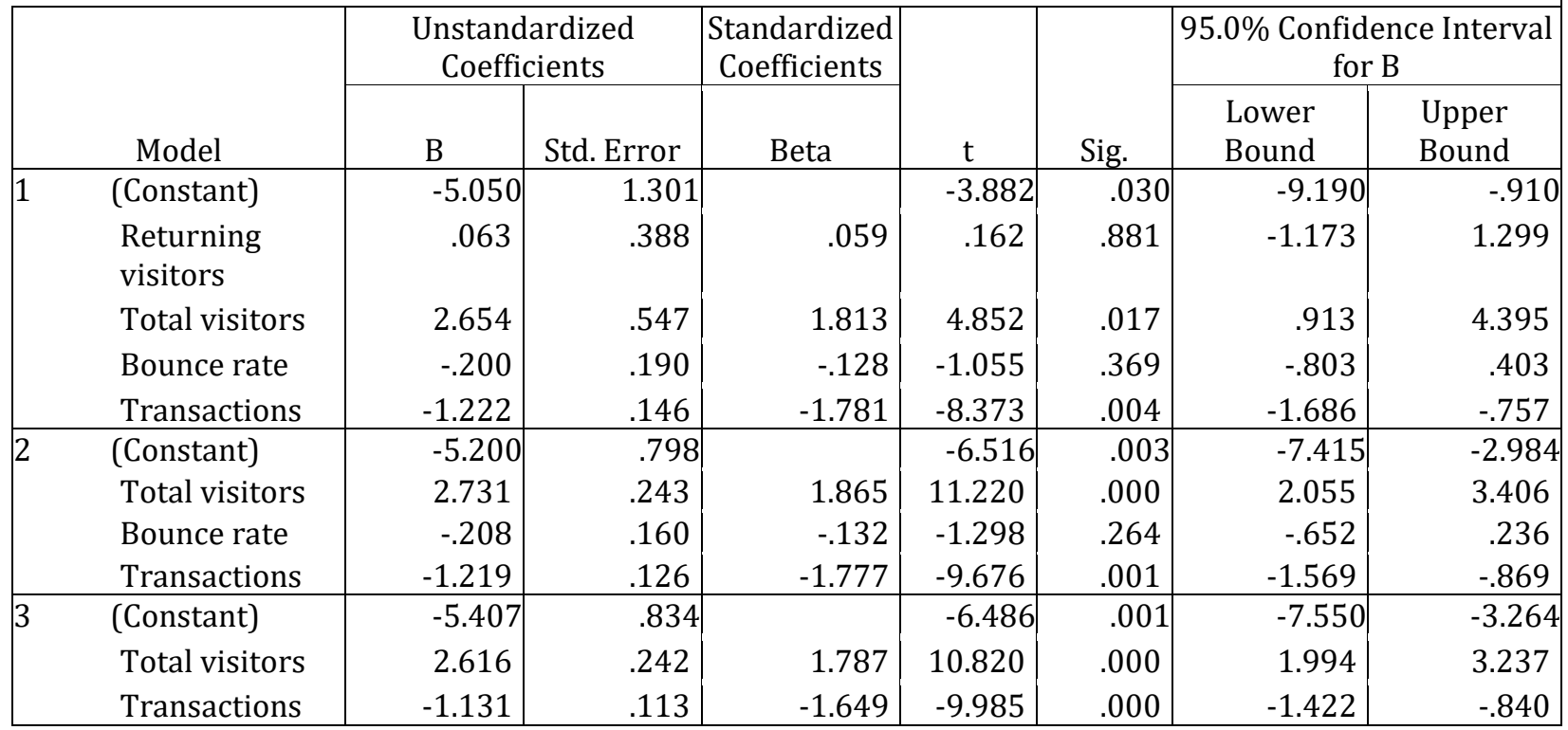

a. Dependent Variable: Net turnover

Source: Authors' own research

Table 7 provides us information about the coefficients of the regression equation. The relevant model for our regression equation is Model 3, which contains a constant and variables Total visitors and Transactions. Thus, the general equation $Y=c+a X 1+b X 2$ can be written as $Y=-5,407+2,616 X 1-1,131 X 2$, where $Y=$ Net turnover, $\mathrm{X} 1=$ Total visitors, and $\mathrm{X} 2=$ Transactions.

Then, we tested if there are any correlations between Net turnover, Revenue, and other variables. For interpreting the data, we used the Evans' guide (1996) for absolute Rvalues, where we have a very strong correlation between 0.8 and 1.0 ; strong correlation for 
values between 0.6 and 0.8 , and a moderate correlation for values between 0.4 and 0.6 (Table 8).

Table 8. Correlation matrix among variables

\begin{tabular}{|c|c|c|c|c|c|r|r|r|r|r|r|c|}
\hline & NT & St & NV & RV & TV & R & \multicolumn{1}{|c|}{ T } & \multicolumn{1}{|c|}{ ECR } & APLT & \multicolumn{1}{l|}{ Co } & E & Y \\
\hline NT & $-.889^{* *}$ & .401 & .323 & .401 & .267 & -.147 & -.482 & -.243 & -.019 & $.813^{*}$ & -.333 \\
\hline $\mathbf{R}$ & .267 & .537 & $.906^{* *}$ & $.887^{* *}$ & $.906^{* *}$ & - & $.833^{*}$ & .583 & .647 & -.019 & .436 & -.527 \\
\hline
\end{tabular}

Note: ${ }^{* *}$. Correlation is significant at the 0.01 level (2-tailed); *. Correlation is significant at the 0.05 level (2tailed). NT - Net turnover; St - Value of stocks; NV - New visitors; RV - Returning visitors; TV - Total visitors; $\mathrm{R}$ - Revenue from online transactions; T - Transactions; ECR - E-commerce Conversion Rate; APLT - Avg. Page Load Time; Co - Company; E - Number of Employees; Y - Founding Year

Source: Authors' own research

\section{Conclusion}

As it can be observed in Table 8, there is a very strong correlation between Net turnover and Stocks $(\mathrm{R}=0.889, \mathrm{p}<0.01)$, and also the number of employees $(\mathrm{R}=0.813, \mathrm{p}<0.05)$. The first correlation gives us the answer to the fourth question, indicating that companies that take the risk of having larger stocks of products also have a higher net turnover.

Revenue is strongly correlated with new visitors $(\mathrm{R}=0.906, \mathrm{p}<0.01)$, returning visitors $(\mathrm{R}=0.887, \mathrm{p}<0.01)$, and total visitors $(\mathrm{R}=0.906, \mathrm{p}<0.01)$. This information gives us an answer to question number 3 formulated at the beginning of the research, indicating that one of the most important dimensions influencing the value of the revenues registered by the online activity is given by the number of online visitors, but also by the number of transactions made by them. Thus, in order to have more sales, companies should invest in advertising campaigns, by Google Ads, in order for the site to be as visible and easier as possible to reach for those interested in industrial products or services. It seems that this value does not take into account the age of the company, the number of employees or the loading time of the web page.

Also, the number of transactions is strongly correlated with online revenue $(\mathrm{R}=0.833$, $\mathrm{p}<0.05$ ). This indicates that online visitors are people who really need a particular industrial product or service and do not visit a site by mistake or just to inform. This observation is also based by analysing the bounce rate. The average value for the eight companies for bounce rate is $56.19 \%$, where for almost every company the new visitors' bounce rate is a little bit higher than the returning visitors one. This rate exceeds 1 percent the normal bounce rate for business to business websites (25-55\%), and 16 percent the normal range for ecommerce and retail websites (20-45\%) (CXL Institute). Also, our average rate for bounce rate is 6 percent higher than the rate for business \& industrial category (50.59\%) but taking into account that this rate is not well above the limit, we can say that our average bounce rate is not a big problem for the eight companies.

By analysing the matrix of correlations, it can be observed that net turnover is not influenced by the numbers of online visitors of the official site of an industrial company that sells services or goods online $(\mathrm{R}<0.401 ; \mathrm{p}>0.05)$ or by the e-commerce conversion rate $(\mathrm{R}=-$ $0.482 ; \mathrm{p}>0.05)$. This may highlight the fact that in the industrial services industry there are still many people who buy goods or services in a classical way - going to a physical store or a representative. In the case of companies that acquire such goods or services, things can also be influenced by the fact that we are talking about a business to business sale where 
transactions are physically concluded, by phone or by mail. Therefore, it is not relevant the website activity in this case where these transactions are not concluded through the website.

This research is not without limitations. First, we limited our research by analysing the financial factor only based on net turnover and the value of stocks. We used that information because we were limited by the official site of the Romanian Ministry of Finance that gave us limited access to financial information and no other information about 2018 balance sheets (they will be available starting with March 2019). Perhaps we should have considered the value of stocks as a control variable rather than a financial indicator.

Second, our partnership with the hosting services Romanian company gave us access to important information about the online activity of industrial services companies, but taking into account the previous information, we needed to choose only companies that were online active in 2017. Thus, our limited number of analyses cases makes this study an exploratory one.

Third, it is possible that some results not to be very accurate for the industrial services companies, because on their sites they provide both the possibility to purchase services and industrial products. Also, many such transactions in this industry may be concluded through physical representatives, which make a large part of the sales value not being recorded through the online site.

Fourth, we cannot present all the indicators that were available on Google Analytics tools, because most of them are confidential data. Therefore, it would be helpful if future researchers would include an agreement with those companies to use their data for scientific purposes, in order to have a more complex view of looking at online performance indicators.

Although the e-commerce industry is still growing in Romania, we cannot ignore the existence of competition. Companies can learn valuable lessons from competitors, especially in e-commerce, which is why they should constantly monitor the evolution of their own company but also the evolution of the competitors and the strategies they address.

The first step could be to identify the online stores of the competitors and to analyse their content and strategies used to interact with clients. Then companies need to use the tools they have at their disposal to analyse their clients and to establish a marketing strategy. After that, companies should analyse the buyers' experience and link them with company data to see if there are any relationships between them and where those links are. Also, continuous monitoring and improvement are required.

\section{References}

Adam, S. \& Deans K. R. (2001). Interstudy comparisons of small business Internet use in Australia and New Zealand. The Seventh Australian World Wide Web Conference. Southern Cross University. Australia: Proceedings of AUSWEB 01, 1-10

Auger, P. (2005). The Impact of Interactivity and Design Sophistication on the Performance of Commercial Websites for Small Businesses. Journal of Small Business Management. 43 (2), 119-37.

Banker, R.D., \& Johnston, H. H. (1995). An empirical study of the business value of the U. S. Airlines computerized reservations system. Journal of Organizational Computing, 5 (3), 255-275.

Barabel, M., \& Meier, O. (2006). Manager. Dunod, Paris 
Bojincă-Moisei, L. (2017). Google Analytics: ghid introductiv. Retrieved from https://ctrld.ro/tips-and-tricks/google-analytics-ghid-introductiv/

Brynjolfsson, E. \& Hitt, L. (2000). Beyond Computation: Information Technology, Organizational Transformation and Business Performance. Journal of Economic Perspectives. 14 (4), 23-48

CXL Institute. Bounce Rate Benchmarks: What's a Good Bounce Rate, Anyway? Retrieved from https://conversionxl.com/guides/bounce-rate/benchmarks/

Evans, J. D. (1996). Straightforward statistics for the behavioral sciences. Pacific Grove, CA: Brooks/Cole Publishing

Fornell, C. \& Larcker, D. F. (1981). Evaluating Structural Equation Models with Unobservable Variables and Measurement Error. Journal of Marketing Research. 18 (1), 39-50.

García, M., García-Nieto, J. \& Aldana-Montes, J. F (2016). An ontology-based data integration approach for web analytics in e-commerce. Expert Systems with Applications, 63 (1), 20-34

Ghandour, A., Benwell, G. \& Deans, K. (2011). Measuring the Performance of eCommerce Websites-An Owner's Perspective. Pacific Asia Journal of the Association for Information Systems. 3 (1), 1-27.

Hair, J.F., Jr., Money, A.H., Samouel, P. \& Page, M. (2007). Research Methods for Business. John Wiley \& Sons, Ltd, Chichester, England

Hemmer, T. (1996). On the design and choice of "modern" management accounting measures. Journal of Management Accounting Research. 8 (1), 87-116.

Jacot, J. H. (1997). De la trilogie: productivité, compétitivité, réntabilité a l'évaluation sociale de la performance industrielle. Entreprese et performance globale. Ed. Economica, Paris

Kaplan, R. S. \& Norton, D. P. (1992). The Balanced Scorecard - Measures that drive performance. Harvard Business Review. 70 (1), 71-79.

Lewis, S. (2013). What is Ecommerce conversion rate in Google analytics?. Retrieved from https://www.quora.com/What-is-Ecommerce-conversion-rate-in-Google-analytics

Mistry, J. (2011). Performance Measurement in the eCommerce Industry. Journal of Business \& Economics Research (JBER). 1 (11), 33-42

Molla, A. \& Licker,P. (2001). E-Commerce System Success: An Attempt to Extend and Respecify the DeLone and McLean model of Success. Journal of Electronic Commerce research. 2 (4), 131-41.

Niculescu, M., \& Lavalette, G. (1999). Strategii de creştere. Ed Economica, Bucuresti,

The Romanian Ministry of Finance. Information on public institutions and economic agents Retrieved from http://www.mfinante.gov.ro/pjuridice.html?pagina=domenii 